\title{
PENDAMPINGAN DAN PELATIHAN INDUSTRI KREATIF IBU - IBU PKK DI KELURAHAN KEROBOKAN SEMARANG
}

\author{
Dwi Nurul Izzhati ${ }^{1}$, Yuniarsi Rahayu ${ }^{2}$ \\ ${ }^{1,2}$ Staf Pengajar Teknik Industri dan Staf Pengajar Teknik Informatika \\ Universitas Dian Nuswantoro Semarang \\ E-mail: ${ }^{1}$ dwi.nurul.izzhati@dsn.dinus.ac.id, ${ }^{2}$ yuniarsi.rahayu@dsn.dinus.ac.id
}

\begin{abstract}
Abstrak
Sesuai dengan tujuan gerakan PKK, perlu ada gerakan teknis dalam mendukung ekonomi keluarga. Untuk mendukung ekonomi keluarga seorang ibu rumah tangga sebagai sasaran khusus PKK, harus mempunyai kemampuan atau kreatifitas terutama dibidang kewirausahaan berbasis industri kreatif, melalui pengabdian masyarakat ini bertujuan untuk membangun talenta keahlian industri kreatif dalam membuat/memproduksi kerajinan macrama dan meningkatkan kemampuan penggunaan Teknologi Informasi sebagai media pemasaran produk macrama yang dihasilkan oleh Ibu-ibu PKK di Kelurahan Kerobokan. Pengabdian ini dilakukan dengan memberikan pelatihan secara singkat selama satu hari yang diikuti 14 peserta dari 30 peserta yang ditargetkan, Berdasarkan hasil pengamatan kegiatan pengabdian masyarakat terlihat ibu-ibu PKK di Kelurahan Kerobokan sangat bersemangat dalam melaksanakan pelatihan terlihat banyaknya peserta yang aktif bertanya dan menunjukkan perhatian yang tinggi. Hasil dari kegiatan pengabdian masyarakat ini adalah ibu-ibu PKK mempunyai semangat kewirausahaan, mempunyai kemampuan memanfaatkan Teknologi Informasi sebagai alat pemasaran dan mampu membuat kerajinan macrama dengan variasi desain layak jual.
\end{abstract}

Kata Kunci: Pemasaran, Teknologi Informasi, Industri Kreatif, Macrama

\section{PENDAHULUAN}

Pemberdayaan keluarga untuk meningkatkan kesejahteraan menuju terwujudnya keluarga yang beriman dan bertaqwa kepada Tuhan Yang Maha Esa, berakhlak mulia dan berbudi luhur, sehat sejahtera, lahir dan batin merupakan tujuan dari gerakan PKK (pkkkotasemarang.org). Untuk mencapai itu semua tentunya perlu ada gerakan yang lebih nyata dan lebih tahnis terutama dalam pemberdayaan keluarga, hal ini sangat penting karena akan menghasilkan kemandirian keluarga, yang mampu berperan dalam pembangunan.

Sasaran PKK adalah keluarga khususnya ibu-ibu rumah tangga, perempuan sebagai sosok sentral keluarga tidak hanya mengurus rumah tangga dan mengasuh anak saja tetapi juga harus mampu mendukung ekonomi keluarga. Untuk mendukung ekonomi keluarga seorang ibu harus mempunyai kemampuan atau kreatifitas terutama dibidang kewirausahaan berbasis industri kreatif.

Kewirausahaan menurut Wikipedia adalah proses mengidentifikasi, mengembangkan, dan membawa visi ke dalam kehidupan.Visi tersebut bisa berupa ide inovatif, peluang, cara yang lebih baik dalam menjalankan sesuatu. Hasil akhir dari proses tersebut adalah penciptaan usaha baru yang dibentuk pada kondisi risiko atau ketidakpastian. Dengan meningkatnya pemahaman dalam strategi pemasaran terutama pemakaian media Teknologi Informasi maka diharapkan dapat mengurangi faktor resiko yang muncul dan mampu melihat peluang pasar serta mampu memenuhi kebutuhan konsumen.

Usaha baru yang ingin diberikan dalam kegiatan pengabdian masyarakat ini adalah Industri yang bersifat kreatif sesuai prioritas program pemerintahan saat ini. Dimana industri kreatif adalah Industri 
yang berasal dari pemanfaatan keterampilan, kreativitas dan bakat individu dalam menciptakan kesejahteraan dan lapangan pekerjaan. Industri ini akan berfokus untuk memberdayakan daya cipta dan daya kreasi suatu individu (Departemen Perdagangan RI: 2009).

Sasaran kegiatan IbM ini adalah Ibu -Ibu PKK di wilayah Kelurahan Kerobokan dengan meningkatkan kemampuan berwirausaha berbasis industri kreatif berupa kerajinan macrame (tali kur), kerajinan ini sangatlah cocok diterapkan karena seni kerajinan macrame (tali kur) mempunyai nilai jual yang cukup tinggi, bisa dibuat berbagai variasi produk yang menarik konsumen dari tas, gelang, tempat HP, kalung, gantungan kunci dll.

Dengan tanpa meninggalkan perannya sebagai seorang ibu rumah tangga diharapkan Ibu-Ibu PKK di Kelurahan Krobokan mempunyai kemandirian ekonomi. Hal ini selaras dengan tujuan gerakan PKK dan program Pemerintah.

\section{METODE PENELITIAN}

Metode pelaksanaan merupakan solusi yang ditawarkan oleh Tim Pengabdian Masyarakat didasarkan pada kendala dan permasalahan yang dialami mitra dalam hal ini ibu-ibu PKK di Kelurahan Krobokan, seperti tabel 1 berikut:

Tabel 1. Metode Pemecahan Masalah Yang Dihadapi Mitra

\begin{tabular}{|c|c|c|}
\hline Masalah yang Harus Ditangani & & $\begin{array}{c}\text { Pemecahan Masalah Yang } \\
\text { Ditawarkan }\end{array}$ \\
\hline $\begin{array}{l}\text { 1. Produksi } \\
\text { Belum mampu membuat/ } \\
\text { memproduksi kerainan } \\
\text { macramé }\end{array}$ & ( & $\begin{array}{l}\text { 1. Pendampingan dan pelatihan } \\
\text { pembuatan Macrame } \\
\text { 2. Pengembangan Desain Macrame }\end{array}$ \\
\hline $\begin{array}{l}\text { 2. Pemasaran } \\
\text { Belum memahami } \\
\text { kewwirausahaan dan Media } \\
\text { Teknologi Informasi sebagai } \\
\text { alat memperluas jaringan } \\
\text { pemasaran. }\end{array}$ & $\square$ & $\begin{array}{l}\text { 1. Pengenalan dan peningkatan } \\
\text { pemahaman PKK di Kelurahan } \\
\text { Krobokan. } \\
\text { 2. Pendampingan dan pemakaian } \\
\text { Media Teknologi Informasi } \\
\text { sebagai media pemasaram. }\end{array}$ \\
\hline
\end{tabular}
berikut:

Adapun kegiatan dan hasil yang dirancang untuk memecahkan permasalahan adalah sebagai
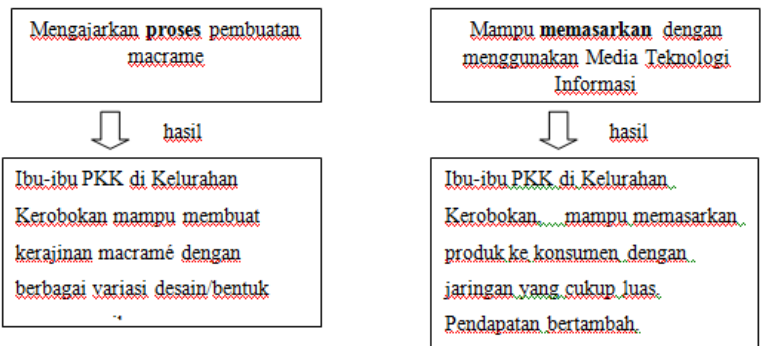

3. HASIL PENELITIAN

Hasil yang telah dicapai dalam kegiatan IbM Pendampingan dan Pelatihan Industri Kreatif IbuIbu PKK Di Kelurahan Kerobokan Semarang adalah berupa pendampingan dan pelatihan di rumah ibu Ketua Gerakan PKK/ Ibu Lurah Ning Setyowati. Alamat pelaksanaan di Jl. Wiroto V no. 3 Kelurahan Krobokan Semarang. Kegiatan telah terlaksana pada hari Minggu, tanggal 7 April 2017 diawali pembukaan dan sambutan oleh ibu Ketua Gerakan PKK/ Ibu Ning Setyowati dan dari Tim IbM diwakili oleh Ibu Dra.Yuniarsi Rahayu, M.Kom. Dilanjutkan foto bersama Tim IbM dan peserta pelatihan. 


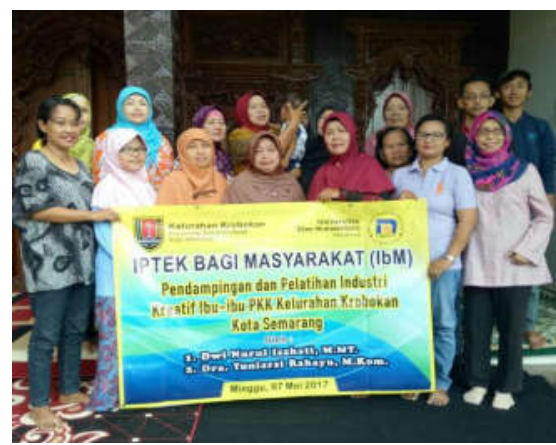

Gambar 1. Foto Bersama Tim IbM dan Peserta Pelatihan

Setelah foto bersama dilakukan pemaparan Pemasaran Industri Kerajinan dengan memanfaatkan Teknologi informasi . Tim IbM memberikan penjelasan tips dan trik memasarkan produk kerajinan memakai teknologi internet.

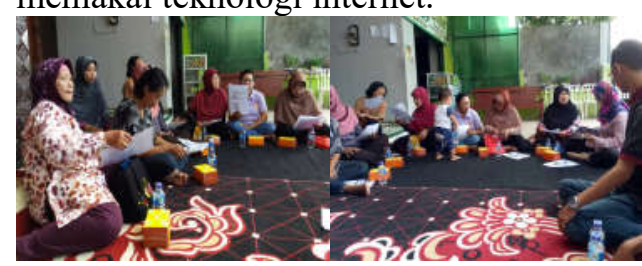

Gambar 2. Peserta Menyimak Ulasan Pemanfaatan Teknologi Informasi

Pemasaran dengan memanfaatkan teknologi informasi (internet/hp) untuk ibu-ibu PKK kelurahan Kerobokan yang sebagian besar sebagai ibu rumah tangga dirasa sangat tepat sekali karena ibu - ibu tersebut tidak perlu bersusah payah keluar dari rumah menjual produk kerajinannya tapi hanya dengan memanfaatkan teknologi informasi ibu-ibu PKK dapat memasarkannya dari rumah tanpa meninggalkan rumah dan anaknya serta pemakaian teknologi informasi ini mampu mempunyai jaringan pembeli yang luas. Pada sesi ketiga diadakan pelatihan pembuatan kerajinan dari macrama adapun peralatan yang disiapkan antara lain: Tali Kur, Gunting, Gantungan Kunci dan Korek Api.

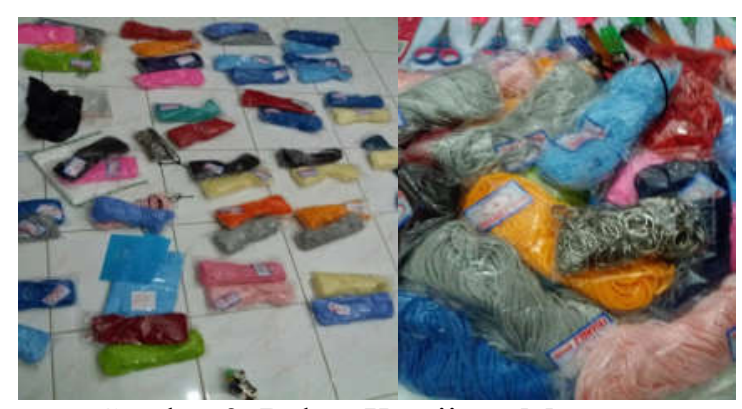

Gambar 3. Bahan Kerajinan Macrama

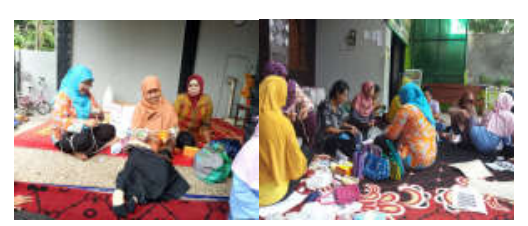




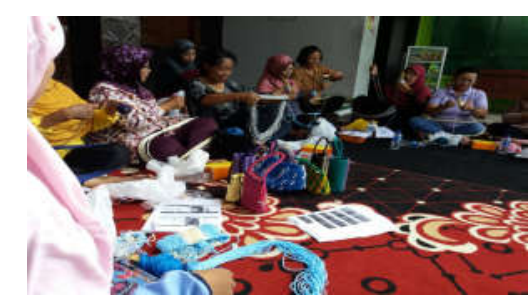

Gambar 4. Pelatihan Macrama Pembuatan Tas dan Gantungan Kunci

\section{KESIMPULAN}

Berdasarkan uraian yang telah di sampaikan sebelumnya, diperoleh kesimpulan bahwa kegiatan pengabdian masyarakat terhadap ibu-ibu PKK di Kelurahan Kerobokan Kota Semarang adalah sebagai berikut:

1. Talenta keahlian industri kreatif Ibu-ibu PKK di Kelurahan Kerobokan dalam membuat/memproduksi kerajinan macrama semakin berkembang, dilakukan dengan pelatihan intensif, mulai memberi tips agar tali kur dapat diurai dengan baik (tidak ruet), pengenalan dasar tali menali, berkembang membuat bros dan membuat tas.

2. Peningkatan kemampuan penggunaan Teknologi Informasi sebagai media pemasaran produk macrama yang dihasilkan oleh Ibu-ibu PKK di Kelurahan Kerobokan dengan cara memberikan penjelasan dalam bentuk ceramah, diskusi dan tanya jawab dan pemberian modul cara-cara pemasaran menggunakan berbagai media Teknologi Informasi.

\section{SARAN}

Berdasarkan hasil pelaksanaan kegiatan pengabdian masyarakat terhadap ibu-ibu PKK di Kelurahan Kerobokan Kota Semarang maka dapat disarankan sebagai berikut: Kegiatan pengabdian masyarakat ini sebaiknya dilakukan berkelanjutan peran serta adanya dukungan dari perangkat pemerintahan setempat seperti RT, RW dan Kelurahan memastikan kegiatan Ibu-ibu PKK di Kelurahan Kerobokan dapat berjalan dengan baik dan kemanfaatannya dapat dirasakan dengan baik untuk kesejahteraan warganya khususnya Ibu-ibu PKK di Kelurahan Kerobokan Kota Semarang.

\section{DAFTAR PUSTAKA}

PKK Kota Semarang, http://pkkkotasemarang.org /tujuan/, akses tanggal 5 Februari 2017 Wikipedia, https://id.wikipedia.org/ wiki/kewirausahaan, akses tanggal 5 Februari 2017 Kemendag, 2009, Program Kerja Pengembangan Industri Kreatif Nasional 2009-2015 Kementrian Perdagangan, Departemen Perdagangan RI, Jakarta. 